\title{
Penggunaan kartu positif-negatif untuk meningkatkan hasil belajar
}

\author{
Ragustini', Rizki Zakwandi \\ 1. SD Negeri Gerbang Raya 3 Kecamatan Periuk Kota Tangerang, Indonesia \\ 2. Program Magister Pendidikan Fisika Universitas Negeri Yogyakarta \\ *ragustini8@gmail.com
}

Received: 24 Mei 2020; Accepted: 23 Desember 2020; Published: 29 Desember 2020

\begin{abstract}
Abstrak
Keberhasilan proses pembelajaran salah satunya dapat dianalisis berdasarkan hasil belajar peserta didik. Pada pelajaran matematika, kemampuan peserta didik dilihat pada kemampuan untuk menjawab soal yang terindeks pada hasil belajar. Tujuan dari penelitian ini adalah untuk meningkatkan hasil belajar peserta didik melalui penggunaan media pembelajaran berupa kartu positif-negatif. Sampel yang digunakan berasal dari kelas V yang berjumlah 24 peserta didik. Hasil penelitian ini menunjukan bahwa media pembelajaran berupa kartu positif-negatif efektif untuk meningkatkan hasil belajar peserta didik. Penelitian selanjutnya dapat mengembangkan aspek-aspek kemampuan berpikir yang ditunjang oleh penggunaan media kartu positif-negatif.
\end{abstract}

Kata kunci: media pembelajaran, kartu positif-negatif, hasil belajar, penelitian tindakan kelas.

\begin{abstract}
The success of the learning process can be analyzed based on the learning outcomes of students. In mathematics, the ability of students can be seen from the ability to answer indexed questions in learning outcomes. The purpose of this study is to improve student learning outcomes by using positive-negative cards as learning media. The sample that used in this research was 24 fifth grade students. The results of this study indicated that positive-negative cards learning media was effective for improving students' learning outcomes. In the further research, it is necessary to carry out research on the aspects of thinking skills which are supported by the use of positive-negative card media.
\end{abstract}

Keywords: Learning media, positive-negative card, learning outcome, classroom action research 


\section{PENDAHULUAN}

Proses pembelajaran (PBM) matematika di tingkat sekolah dasar memiliki tujuan untuk membentuk pondasi berpikir logis kepada peserta didik untuk memudahkan mencapai tingkat selanjutnya (Widyastuti \& Pujiastuti, 2014). Dalam pelaksanaannnya, peserta didik diharapkan mampu menemukan solusi dari setiap permasalahaan yang diberikan. Guru memiliki peranan yang besar dalam memfasilitasi peserta didik demi tercapainya hasil belajar yang baik (Febriyanti \& Seruni, 2015) dan menjadi indikator keberhasilan guru dalam mengajar.

Peranan guru dalam memfasilitasi pembelajaran dapat mempengaruhi motivasi, prestasi dan perilaku peserta didik. Selain itu, kemampuan guru dalam mengorganisasi kelas dan mengoptimalkan lingkungan fisik yang berada di kelas membuat peserta didik berada dalam level kenyamanan emosi dan meningkatkan kualitas komunikasi antar guru dan peserta didik. Kedua hal tersebut menjadi faktor penting dalam suatu keberhasilan pembelajaran yang mana bisa menjadi faktor pendukung atau penghambat pembelajaran yang optimal (Febriyanti \& Seruni, 2015). Faktor pendukung dan penghambat dalam pembelajaran perlu diperhatikan agar tercapainya indikator pembelajaran.

Pembelajaran matematika di tingkat sekolah dasar sering kali mendapatkan stigma negatif, dipandang cukup sulit dan kurang diminati oleh peserta didik. Hal ini disebabkan oleh fundamen pembelajaran matematika yang cenderung menekankan pada pemikiran logis yang terkadang belum mampu diikuti dan dikuasai sepenuhnya oleh peserta didik (Waskitoningtyas, 2016). Selain itu, tuntunan kurikulum dengan menerapkan pembelajaran berbasis tematik juga memberikan beberapa kendala bagi guru. Kendala bagi guru diantaranya adalah kesulitan dalam mengaitkan antara mata pelajaran matematika dengan konteks pembelajaran lainnya, dan kesulitan dalam merancang pembelajaran tematik yang sangat padu (Wahyuni, Setyosari, \& Kuswandi, 2016).

Studi pendahuluan yang dilakukan memberikan gambaran bahwa peserta didik banyak mengalami kesulitan dan tidak termotivasi untuk balajar, khususnya pada materi operasi bilangan. Hal ini didasarkan dari data yang diperoleh pada hasil tes formatif yang diberikan yang menunjukan hasil belajar yang rendah. Selain itu, hasil tes pendahuluan menunjukan bahwa hanya 20,8\% peserta didik yang memenuhi standar Kriteria Ketuntasan Minimum (KKM) sedangkan sisanya sebanyak $79,2 \%$ belum memenuhi KKM. Rata-rata hasil belajar peserta didik pada tes formatif awal adalah 56,7 yang tergolong rendah dalam daya penjelas. Fakta tersebut menandakan bahwa diperlukan sebuah upaya dan pembenahan pembelajaran pada materi operasi bilangan bulat agar hasil belajar peserta didik dapat mengalami peningkatan. Karena jika hal tersebut tidak diatasi sehingga siswa tidak menguasi konsep operasi hitung bilangan bulat, maka peserta didik akan mengalami kesulitan dalam mengikuti pelajaran selanjutnya (Rachmawati, Suhendar, \& Akbar, 2018)

Berdasarkan analisis situasi yang dilakukan diperoleh gambaran mengenai permasalahan pembelajaran yang dihadapai peserta didik dengan identifikasi masalah antara lain: 1) Peserta didik kurang fokus pada materi pelajaran di saat pembelajaran berlangsung; 2) Peserta didik tidak dapat menyelesaikan soal evaluasi pembelajaran dengan baik; dan 3) Peserta didik kurang termotivasi selama pembelajaran pada materi operasi bilangan bulat. Menurut Rahimah dan Asy'ari (2017) dan Susilawati (2015), terdapat beberapa alasan untuk masalah tersebut diantaranya: 1) Proses pelaksanaan pembelajaran masih bersifat teacher center; 2) Guru masih kurang optimal dalam penjelasan materi kepada peserta didik, 3) Guru mengajar tanpa dibantu media pengajaran yang menarik minat peserta didik untuk lebih aktif dalam pembelajaran , 4) Peserta didik jarang diberi kesempatan untuk 
bertanya atau mengemukakan pendapat sehingga menyebabkan kurang terbentuknya interaksi dan komunikasi sesama peserta didik maupun dengan guru.

Febriyanti dan Seruni (Febriyanti \& Seruni, 2015) menemukan solusi untuk mengatasi hal tersebut yaitu dengan meningkatkan interaksi antara guru dan peserta didik selama pembelajaran dan dengan menggunakan media pembelajaran. Peningkatan kuantitas dan kualitas interaksi dinilai mampu meningkatkan hasil belajar, motivasi peserta didik, dan sebagai jalan tengah bagi guru. Upaya peningkatan interaksi pembelajaran dapat dilakukan melalui pemanfaatan siklus belajar atau learning cycle (Rahayuningsih, Masykuri, \& Utami, 2012). Pemanfaatan media pembelajaran mampu mendukung proses belajar mengajar agar pembelajaran lebih efektif, menarik, dan tepat sasaran (Pitriana, Agustina, Zakwandi, Ijharudin, \& Kurniawan, 2018).

Penelitian ini bertujuan untuk meningkatkan hasil belajar peserta didik melalui pembelajaran learning cycle yang dibantu dengan menggunakan media pembelajaran. Media pembelajaran yang digunakan adalah kartu positif dan kartu negatif. Penggunaan kartu positif dan kartu negatif memungkinkan peserta didik untuk langsung mempraktekan ke bilangan bulat positif dan negatif, sehingga pembelajaran akan lebih bermakna, aktif dan menyenangkan (Farida, 2018; Putri, 2016) Selain itu, berdasarkan studi dari Panjaitan (2015), dan Sinaga (2018) pembelajaran dengan mengunakan kartu positif-negatif dinilai efektif dalam meningkatkan hasil belajar dan penguasaan konsep peserta didik. Hal ini sejalan dengan penelitian Rachmawati, Suhendar, dan Akbar (2018) bahwa siswa lebih tertarik untuk menggunakan kartu positifnegatif karena dapat langsung mempraktekan sehingga konsep tentang operasi hitung bilangan bulat pun mudah diterima (Rachmawati et al., 2018).

\section{METODE}

Jurnal Analisa 6 (2) (2020) :187-196
Penelitian ini merupakan penelitian tindakan kelas yang subyeknya adalah siswa kelas VA di salah satu SDN Kota Tangerang tahun pelajaran 2016-2017. Subjek pada penelitian sebanyak 24 orang. Proses penelitian ditunjukkan pada Gambar 1.

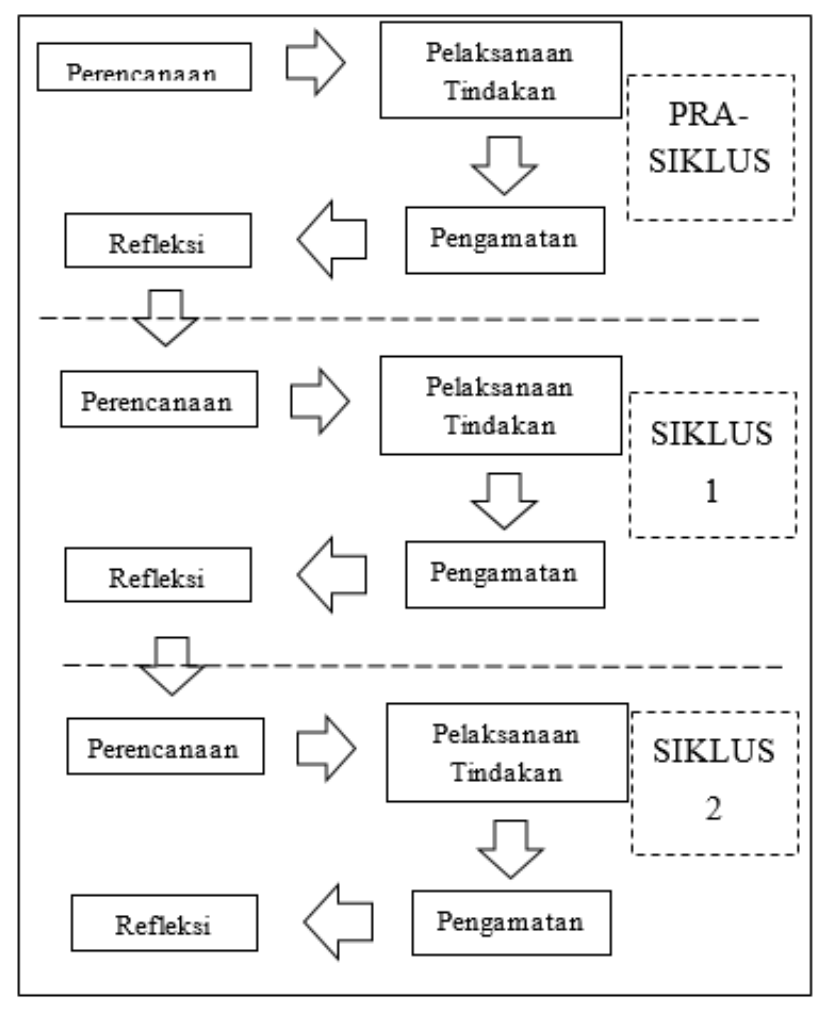

Gambar 1. Alur Penelitian

Proses penelitian terdiri dari empat tahap, dimulai dengan perencanaan tindakan, pelaksanaan tindakan, observasi dan diakhiri dengan refleksi. Refleksi dilakukan pada tahap pra siklus dan diulangi pada siklus berikutnya. Sebelum pelaksanaan penelitian dilaksanakan observasi awal terhadap hasil belajar peserta didik, kemudian diadakan penelitian siklus 1 diawali dengan tahap perencanaan, kemudian pelaksanaan tindakan kelas.

\subsection{Pra Siklus}

Langkah pertama pada kegiatan pra siklus adalah menyiapkan Rencana Pelaksanaan 
Pembelajaran (RPP) sebagaimana proses pembelajaran sebelumnya. Dalam tahap pra siklus, hasil observasi terhadap aktivitas peserta didik digunakan untuk menyiapkan langkah evaluasi dan digunakan sebagai rujukan untuk menyusun treatmen pada tahap berikutnya. Tahapan terakhir pada kegiatan pra siklus adalah refleksi berupa mencermati, mengkaji, dan menganalisis secara mendalam dan menyeluruh tindakan yang telah dilaksanakan pada langkah evaluasi. Hasil analisis tersebut akan digunakan sebagai acuan untuk merencanakan tindakan selanjutnya. Berdasarkan analisis tersebut maka disusunlah rencana kegiatan yang baru yang akan dilaksanakan pada tahap siklus 1 .

\subsection{Silkus 1}

\section{a. Perencanaan}

Berdasarkan kendala yang diemukan pada tahap pra siklus maka dilakukan tindakan yang akan memecahkan masalah tersebut. Adapun langkah kegiatan yang dilakukan pada tahapan perencanan tindakan siklus 1 meliputi: a) Menyiapkan silabus dan RPP, b) Menyiapkan skenario pembelajaran, c) Menyiapkan materi pembelajaran, d) Menyiapkan media pembelajaran e) Menyiapkan soal pertanyaan f) Menyiapkan lembar jawaban peserta didik, g) Menyiapkan lembar penilaian peserta didik.

\section{b. Tindakan}

Tahap kedua dari penelitian ini adalah perlakuan yang diberikan kepada siswa sebagai upaya untuk meningkatkan hasil belajar peserta didik. Rancangan kegiatan pembelajaran meliputi tiga tahap yaitu kegiatan awal, kegiatan inti dan kegiatan akhir. Secara spesifik, kegiatan-kegiatan yang dilakukan selama proses pembelajaran adalah sebagai berikut: a) Kegiatan pembelajaran dimulai dengan guru menjelaskan tujuan pembelajaran atau kompetensi yang akan dicapai, b) Menyampaikan pokok-pokok materi pembelajaran, c) Guru memberikan beberapa soal hitungan untuk dijawab cepat oleh peserta didik sebagai apersepsi pembelajaran, d) Guru membagi peserta didik menjadi 6 kelompok, setiap kelompok terdiri dari 4 orang peserta didik, e) Guru meminta setiap peserta didik mengeluarkan kartu positif dan kartu negatif (lihat gambar 2) miliknya, f) Setiap kelompok peserta didik mengerjakan 10 soal hitungan berkaitan dengan materi bilangan bulat dengan memanfaatkan kartu positif dan kartu negatif sebagai media hitung, g) Guru memberi saran dan kesimpulan dari hasil kerja setiap kelompok peserta didik.

\section{c. Observasi}

Observasi berkaitan dengan analisa guru atau peneliti terkait pelaksanaan proses pembelajaran. Pada tahap ini peneliti menentukan hal-hal yang perlu diperbaiki agar treatment yang direncanakan dalam proses pembelajaran dapat mencapai tujuan yang diinginkan. Hasil dari observasi juga dapat menemukan kelemahan-kelemahan serta kendala dalam proses pembelajaran kemudian dijadikan dasar perbaikan rencana tindakan pada siklus berikutnya.

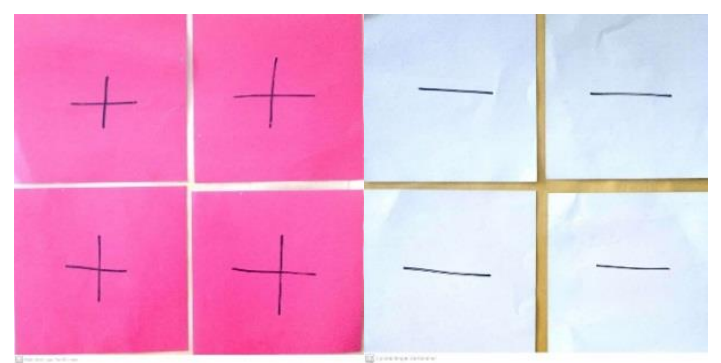

\section{Gambar 2. Model Kartu Positif Negatif}

\section{d. Refleksi}

Kegiatan refleksi berisikan kajian dan analsisis secara mendalam serta menyeluruh terkait tindakan yang telah diberikan. Analisis dilakukan berdasarkan data yang telah terkumpul pada langkah observasi. Hasil yang diperoleh dari observasi dikumpulkan dan dianalisis sehingga dapat diketahui apakah kegiatan yang dilaksanakan sesuai dengan 
tujuan yang direncanakan. Hasil analisis tersebut akan digunakan sebagai acuan untuk merencanakan tindakan selanjutnya pada siklus 2 hingga permasalahan yang ada dapat teratasi. Aspek-aspek yang ditinjau pada kegiatan refleksi diri meliputi penjelasan konsep, alat peraga yang digunakan, metode mengajar, pengelolaan kelas, dan aktifitas peserta didik selama pembelajaran.

\subsection{Siklus 2}

\section{a). Perencanaan}

Pada siklus 2 dilakukan tindakan seperti pada siklus 1 dengan memperbaiki segala keterbatasan dan kekurangan yang ditemukan pada pelaksanaan siklus 1 .

\section{b). Tindakan}

Tahap kedua dari penelitian ini adalah pelaksanaan upaya peningkatan hasil belajar peserta didik melalui tindakan perbaikan pembelajaran.

\section{c). Observasi}

Siklus 2 merupakan siklus terakhir dalam rangkaian penelitian tindakan kelas yang dilaksanakan sehingga pada tahap observasi peneliti hanya mengambil data terkait kemampuan akhir peserta didik dan mengamati tingkat keefektifan pembelajaran yang dilaksanakan dengan menggunakan media kartu positif-negatif.

\section{d). Refleksi}

Kegiatan pada langkah ini adalah mencermati, mengkaji, dan menganalisis secara mendalam dan menyeluruh tindakan yang telah dilaksanakan berdasarkan data yang telah terkumpul pada langkah evaluasi siklus 1 dan siklus 2. Hasil analisis tersebut akan digunakan sebagai acuan hasil penelitian. Aspek-aspek yang ditinjau pada kegiatan refleksi diri meliputi penjelasan konsep, alat peraga yang digunakan, metode mengajar, pengelolaan kelas, dan aktifitas peserta didik selama pembelajaran.

\section{HASIL DAN PEMBAHASAN}

\subsection{Pra Siklus}

Pada tahap pra siklus, pemahaman peserta didik terhadap operasi hitung bilangan bulat sangat kurang. Aktivitas belajar peserta didik sangat rendah dan peserta didik cenderung pasif saat kegiatan pembelajaran berlangsung. Dari 24 peserta didik hanya beberapa peserta didik yang nilainya mencapai KKM sekolah yang telah ditentukan yaitu 75 . Hal ini dikarenakan ada beberapa kekurangan antara lain pada saat pembelajaran berlangsung media pembelajaran/alat peraga yang digunakan berupa garis bilangan kurang dapat memotivasi peserta didik. Hanya sebagian peserta didik saja yang mau membuat garis bilangan, sedangkan peserta didik yang lain hanya diam menunggu hasil jawaban yang didapat oleh temannya. Permasalahan ini menjadi acuan peneliti untuk melakukan perbaikan pembelajaran, sampai materi pelajaran tersebut benar-benar dapat dimengerti dan dipahami oleh peserta didik.

Berdasarkan data pre-test yang diberikan terlihat bahwa peserta didik yang mencapai nilai di atas KKM sekolah yaitu sebanyak 5 orang, atau sebesar 20,8 \%, sedangkan peserta didik yang mendapat nilai dibawah KKM yang ditentukan sekolah yaitu sebanyak 19 orang atau sebesar 79,2 \%. Hasil tersebut dapat terlihat dapat Gambar 3 .

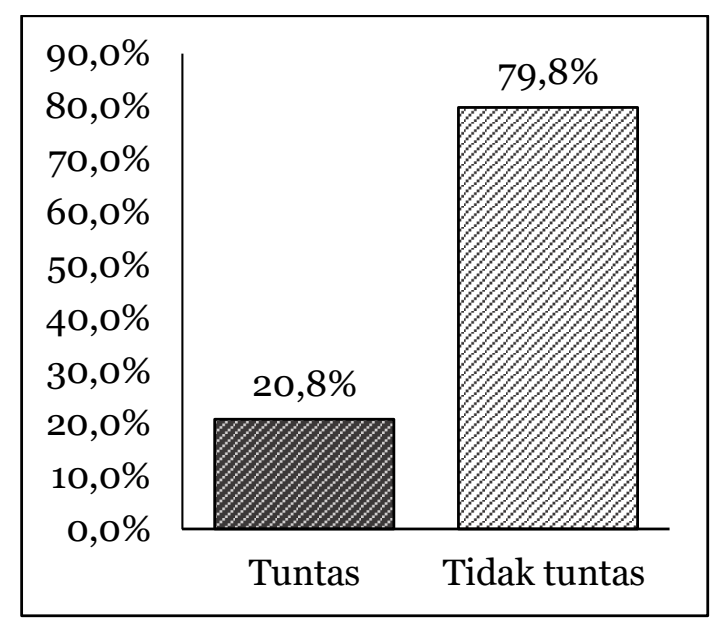

Gambar 3. Grafik ketuntasan Belajar Pra Siklus 
Berdasarkan persentase pada Gambar 3, ketuntasan belajar peserta didik pada tahap pra siklus ini sangat rendah. Sebagai bahan refleksi, dilakukan refleksi bersama terhadap tahap pra siklus seperti pada Tabel 1 .

Tabel 1. Refleksi Diri

\begin{tabular}{|c|c|c|c|c|}
\hline \multirow[t]{2}{*}{ No } & \multirow{2}{*}{ Aspek } & \multicolumn{2}{|c|}{ Kemunculan } & \multirow{2}{*}{ Hasil } \\
\hline & & Ada & Tidak & \\
\hline 1 & $\begin{array}{l}\text { Pen- } \\
\text { jelasan } \\
\text { konsep }\end{array}$ & $\checkmark$ & & Kurang \\
\hline 2 & $\begin{array}{c}\text { Alat } \\
\text { peraga }\end{array}$ & $\checkmark$ & & Kurang \\
\hline 3 & $\begin{array}{c}\text { Metode } \\
\text { meng- } \\
\text { ajar }\end{array}$ & & $\checkmark$ & Kurang \\
\hline 4 & $\begin{array}{l}\text { Peng- } \\
\text { elolaan } \\
\text { kelas }\end{array}$ & $\checkmark$ & & Kurang \\
\hline 5 & $\begin{array}{l}\text { Akti- } \\
\text { vitas } \\
\text { peserta } \\
\text { didik }\end{array}$ & $\checkmark$ & & Kurang \\
\hline
\end{tabular}

Berdasarkan hasil refleksi pada Tabel 1, diperoleh gambaran bahwa masih terdapat beberapa aspek yang belum muncul dan beberapa lainnya masih belum optimal.

\subsection{Siklus 1}

Dalam melaksanaan pembelajaran pada siklus 1 ini penulis diamati oleh teman sejawat yang duduk di belakang peserta didik. Hasil pengamatan teman sejawat terhadap penulis dapat dilihat pada Tabel 2.

Tabel 2. Refleksi Diri Siklus 1

\begin{tabular}{|c|c|c|c|}
\hline \multirow[t]{2}{*}{ No } & \multirow{2}{*}{ Aspek } & Kemunculan & \multirow{2}{*}{ Hasil } \\
\hline & & Ada $\quad$ Tidak & \\
\hline 1 & $\begin{array}{c}\text { Pen- } \\
\text { jelasan } \\
\text { konsep }\end{array}$ & $\checkmark$ & Cukup \\
\hline
\end{tabular}

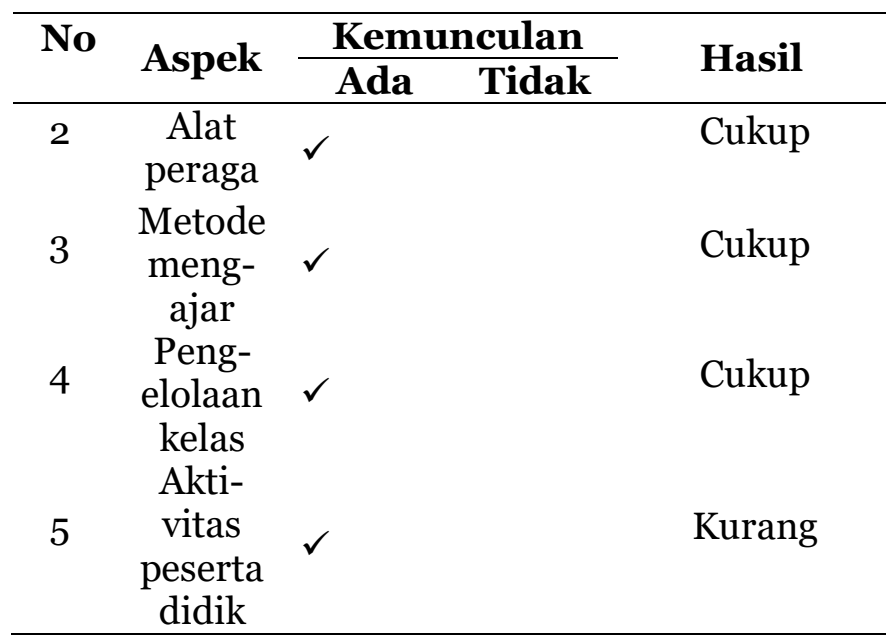

Setelah dilakukan kegiatan pembelajaran pada siklus 1, diadakanlah evaluasi secara tertulis. Adapun nilai evaluasi peserta didik pada siklus 1 dapat dilihat pada Gambar 4.

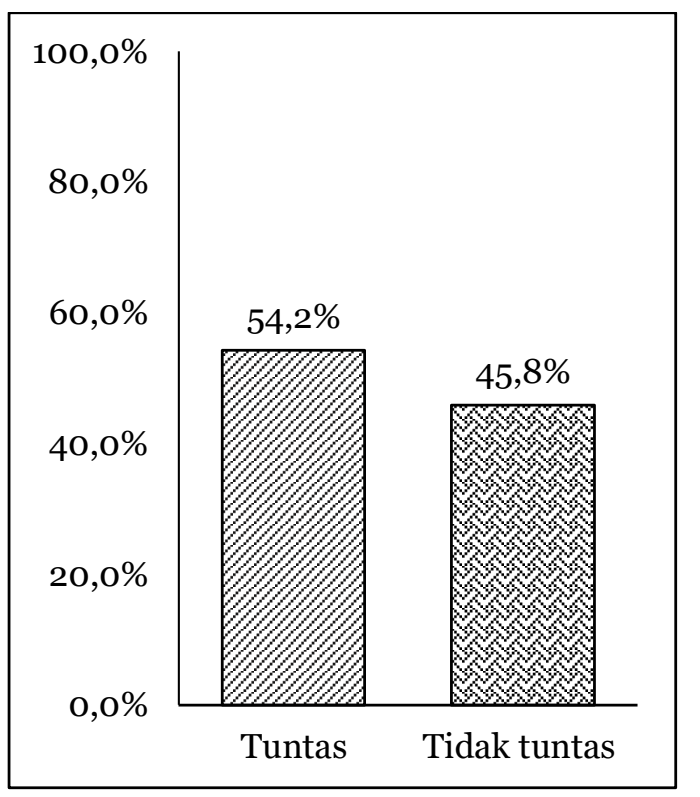

Gambar 4. Grafik Ketuntasan Belajar Siklus 1

Berdasarkan Gambar 4, dapat disimpulkan bahwa dari sejumlah 24 orang peserta didik, sebanyak 13 orang peserta didik yang mencapai nilai di atas KKM atau sebesar 54,2 \%, sedangkan yang mendapat nilai dibawah KKM yang ditentukan sekolah yaitu sebanyak 11 orang atau sebesar 45,8 \%. Data ini 
menunjukkan adanya peningkatan jumlah dan persentase peserta didik yang mencapai nilai KKM yaitu sebesar $33,4 \%$ dari pra siklus. Merujuk pada Tabel 2, juga terdapat peningkatan capaian refleksi dimana terdapat peningkatan kualitas interaksi yang berlangsung. Meskipun demikian, masih terdapat beberapa catatan yang perlu diperbaiki yaitu: 1) masih terdapat siswa yang tidak fokus selama pembelajaran, 2) masih terdapat siswa yang belum dapat mengikuti kegiatan pembelajaran secara maksimal. Hal ini perlu diperbaiki sehingga menjadi catatan dalam pembelajaran dalam siklus 2 .

\subsection{Siklus 2}

Pelaksanaan siklus 2 merupakan tahap akhir dari pembelajaran pada penelitian ini. Refleksi sebagai hasil pengamatan keterlaksanaan pembelajaran terdapat dalam Tabel 3 .

Tabel 3. Refleksi Diri Siklus 2

\begin{tabular}{|c|c|c|c|}
\hline \multirow[t]{2}{*}{ No } & \multirow[t]{2}{*}{ Aspek } & Kemunculan & \multirow[t]{2}{*}{ Hasi } \\
\hline & & Tidak & \\
\hline 1 & $\begin{array}{c}\text { Pen- } \\
\text { jelasan } \\
\text { konsep }\end{array}$ & $\checkmark$ & Baik \\
\hline 2 & $\begin{array}{c}\text { Alat } \\
\text { peraga }\end{array}$ & $\checkmark$ & Baik \\
\hline 3 & $\begin{array}{l}\text { Metode } \\
\text { meng-ajar }\end{array}$ & $\checkmark$ & Baik \\
\hline 4 & $\begin{array}{l}\text { Peng- } \\
\text { elolaan } \\
\text { kelas }\end{array}$ & $\checkmark$ & Baik \\
\hline 5 & $\begin{array}{l}\text { Aktivitas } \\
\text { peserta } \\
\text { didik }\end{array}$ & $\checkmark$ & Baik \\
\hline
\end{tabular}

Berdasarkan Tabel 3, keterlaksanaan pembelajaran di semua aspek sudah memperoleh catatan yang baik. Hasil ini memberikan refleksi bahwa siklus pembelajaran dapat meningkatkan kesiapan dan kemampuan guru dalam menyusun dan mengorganisasikan pembelajaran.

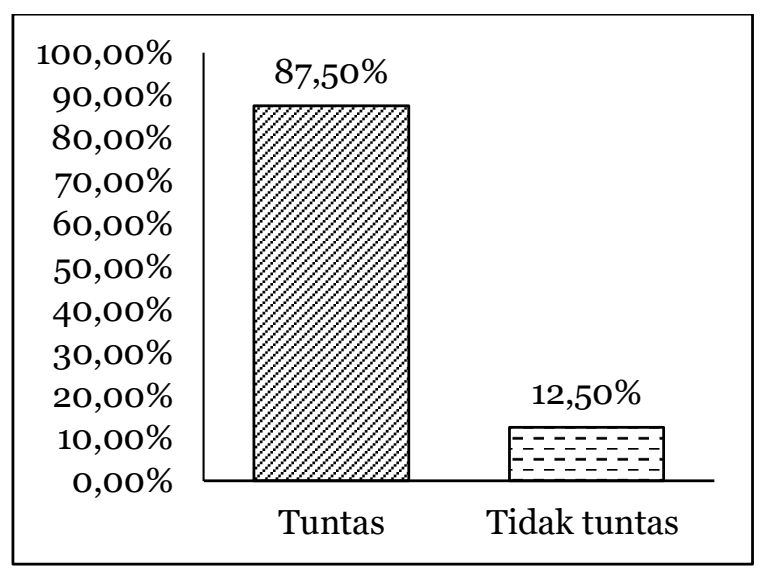

\section{Gambar 5. Grafik ketuntasan Siklus 2}

Berdasarkan Gambar 5 dapat kita lihat bahwa dari sejumlah 24 orang peserta didik kelas VA, peserta didik yang mencapai nilai di atas KKM yang ditentukan sekolah yaitu sebanyak 21 orang, atau sebesar $87,5 \%$, sedangkan peserta didik yang mendapat nilai dibawah KKM yang ditentukan sekolah yaitu sebanyak 3 orang atau sebesar $12,5 \%$. Data ini menunjukkan adanya peningkatan jumlah peserta didik yang mencapai nilai KKM yaitu sebesar 33,3\% lagi, dari siklus 1 sebesar 54,2\% naik menjadi 87,5\% pada siklus 2. Jika diamati persentase keberhasilan peserta didik yang mencapai nilai KKM pada setiap siklus, maka diperoleh gambaran bahwa adanya peningkatan yang cukup signifikan di setiap pertemuan. Untuk lebih jelasya dapat dilahat pada Gambar 6 .

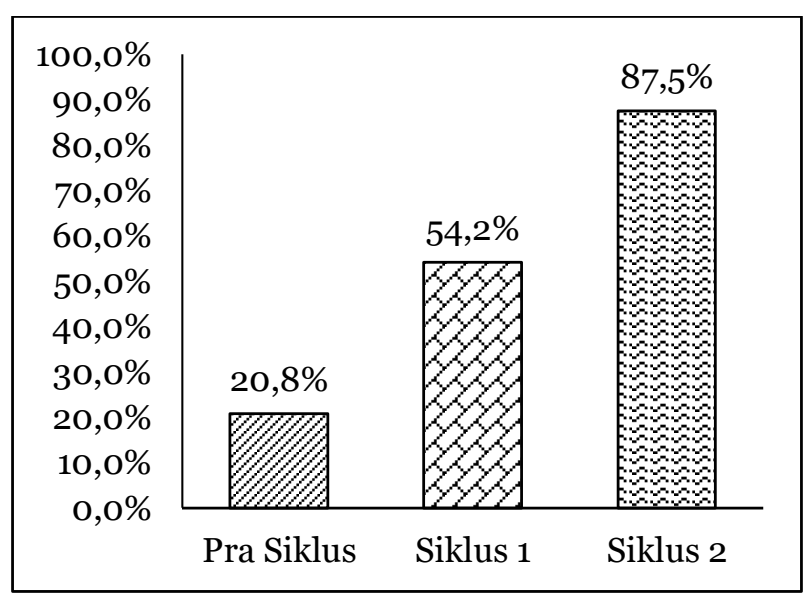

Gambar 6. Grafik Peningkatan Hasil Belajar 
Berdasarkan Gambar 6, diperoleh hasil analisis berupa nilai $\mathrm{N}$-gain dari masing-masing peningkatan. Nilai $\mathrm{N}$-gain antara pra siklus 1 dan pra siklus adalah 0.42 dengan interpretasi sedang. Selanjutnya nilai N-gain dari siklus 2 ke siklus 1 menunjukan adalah 0.72 dengan inerpretasi tinggi, dan untuk nilai N-gain akhir (siklus 2 terhadap pra siklus) adalah 0.84 dengan interpretasi tinggi (Hake, 1999). Hasil ini menunjukan bahwa terdapat peningkatan hasil belajar yang signifikan di setiap siklus ataupun secara keseluruhan.

\subsection{Peningkatan Hasil Belajar}

Penggunaan media pembelajaran kartu positifnegatif melalui pembelajaran siklus mampu meningkatkan hasil belajar matematika materi operasi bilangan. Peningkatan hasil belajar yang diperoleh juga diikuti dengan peningkatan aktivitas belajar. Berdasarkan hasil studi yang dilakukan, terdapat peningkatan aktivitas belajar dan hasil yang diberikan pada setiap siklus.

Pada pelaksanaan pembelajaran normal, dengan menggunakan media pembelajaran garis bilangan, sebagian besar peserta didik tidak terlibat secara aktif dalam kegiatan pembelajaran dan asik dengan aktivias masingmasing. Hal ini berimbas pada hasil capaian KKM yang mana hanya $20.8 \%$ siswa yang memperoleh nilai diatas KKM. Hal ini salah satunya disebabkan oleh media yang digunakan yang mana tidak memberikan daya tarik (kurang menarik) perhatian siswa sehingga motivasi dan kemauan belajar masih rendah. Kesimpulan ini sejalan dengan temuan penelitian. Hal ini didasarkan pada temuan penelitian Agustina dkk (2018) dan penelitian Pitriana dkk (Pitriana et al., 2018) yang menyatakan bahwa media pembelajaran yang menarik akan membuat siswa fokus dan meningkatkan motivasi belajarnya.

Penggunaan media pembelajaran berupa kartu positif-negatif memberikan kesempatan pada siswa untuk terlibat lebih aktif dalam proses pembelajaran. Siswa yang diminta untuk membuat kartu terlihat seperti sedang bermain sehingga menimbulkan semangat dalam pembelajaran. Berdasarkan aktivitas pembelajaran, terdapat peningkatan bentuk interaksi yang dilakukan di setiap siklus. Hasil studi ini sejalan dengan temuan dari Rahayuningsih (Rahayuningsih et al., 2012) dan Hikmah (2016) yang menyatakan bahwa penerapan siklus pembelajaran dapat meningkatkan kemampuan siswa. Selain itu, hasil temuan ini juga mengindikasikan bahwa media pembelajaran yang digunakan dinilai mampu meningkatkan hasil belajar siswa. Menurut panjaitan (Panjaitan, 2015) dan Mahmud (2020), peningkatan ini disebabkan karena beberapa faktor, diantaranya adalah keterlibatan siswa dalam pembalajaran dan pelaksanaan pembelajaran yang cenderung menyenangkan membuat kesan pembelajaran menjadi lebih baik.

Secara keseluruhan, penggunaan media pembelajaran berupa kartu positif-negatif dinilai efektif untuk meningkatkan aktivitas belajar dan hasil belajar siswa pada materi operasi bilangan. Pada setiap siklus, terlihat bahwa jumlah siswa yang mampu menuntaskan KKM semakin meningkat. Hingga pada akhir siklus ke-2, hanya $12.5 \%$ siswa yang masih mengalami kesulitan untuk menyelesaikan permasalahan terkait operasi bilangan. Peningkatan yang ditunjukan dengan nilai $\mathrm{N}$-gain juga relative tinggi yaitu 0.42 pada siklus pertama dengan interpretasi sedang dan 0.72 pada siklus kedua dengan interpretasi tinggi. Hasil ini sejalan dengan temuan dari Panjaitan (Panjaitan, 2015), dan Sinaga (Sinaga, 2018) yang menyatakan bahwa penggunaan kartu positif-negatif efektif untuk meningkatkan hasil belajar peserta didik. Faktor lainnya yang mempengaruhi hal tersebut adalah dengan adanya siklus belajar dimana peserta didik diberikan materi secara komprehensif pada dua tahap. Liana (2020) dan Haryati (2019) menjelaskan bahwa pengulangan materi secara komprehensif akan memberikan peserta didik pengalaman belajar yang lebih banyak, sehinga peserta didik akan mampu menyerap lebih banyak informasi. Dengan adanya kontribusi dari media 
pembelajaran, peserta didik akan merasa lebih nyaman untuk melakukan pembelajaran.

Penelitian tindakan kelas ini merupakan sebuah langkah taktis yang dilakukan untuk mengatasi lemahnya kemampuan siswa pada materi operasi bilangan. Sebagai sebuah penelitian tindakan kelas, penelitian ini memiliki keterbatasan dalam hal generalisasi. Akan tetapi, hasil dari studi yang dilakukan dapat dijadikan sebagai referensi dalam hal melakukan penelitian serupa.

\section{KESIMPULAN}

Penelitian tindakan kelas ini menyimpulkan bahwa dengan menggunakan media pembelajaran berupa kartu positif-negatif terbukti dapat memberikan hasil yang positif terhadap peningkatan hasil belajar peserta didik. Pelaksanaan pembelajaran melalui dua siklus pengulangan menunjukan membuat peserta didik aktif dalam kegiatan pembelajaran sehingga dapat meningkatkan pemahaman mereka terhadap materi pelajaran yang sedang diajarkan. Secara keseluruhan, terdapat peningkatan persentase ketuntasan pembelajaran dari setiap siklus yang dilakukan. Selain itu, peningkatan hasil belajar juga ditunjukan oleh nilai N-gain dengan interpretasi tinggi. Diharapkan, penelitian ini dapat memberikan pilihan pembelajaran matematika di sekolah dasar agar peserta didik mendapatkan hasil belajar yang lebih baik.

\section{REFERENSI}

Agustina, R. D., Muhammad Minan Chusni, Winda Setya, \& Rizki Zakwandi. (2018). Respon peserta didik dalam praktikum fluida statis menggunakan alat roberval balance. Jurnal Pendidikan Fisika Universitas Muhammadiyah Metro, 6(1), 76-83.

https://doi.org/http://dx.doi.org/10.2412 7/jpf.v6i1.1046

Farida, B. (2018). Penerapan pendekatan matematika realistik dalam peningkatan keaktifan dan hasil belajar matematika di Kelas iii Sekolah Dasar Negeri 4 Tanggung. Jurnal Ilmiah Pendidikan Dasar, 4(2), 81. https://doi.org/10.30659/pendas.4.2.8190

Febriyanti, C., \& Seruni, S. (2015). Peran minat dan interaksi siswa dengan guru dalam meningkatkan hasil belajar matematika. Formatif: Jurnal Ilmiah Pendidikan MIPA, 4(3), 245-254. https://doi.org/10.30998/formatif.v4i3.1 61

Hake, R. R. (1999). Analizing Change/ Gains Scores.

Haryati, T. (2019). Peningkatan hasil belajar matematika model belajar sambil bermain perbantuan media monopoli (PTK Matematika kelas III SD Negeri Nyimplung Tahun 2017). Jurnal Penelitian Guru FKIP Universitas Subang, O2(01), 187-194. https://doi.org/10.1017/CBO97811074153 24.004

Hikmah, N. (2016). Peningkatan hasil belajar matematika tentang penjumlahan dan pengurangan bilangan bulat melalui alat peraga mistar bilangan pada siswa kelas IV SDN 005 Samarinda Ulu. Nurul Hikmah. Jurnal Pendas Mahakam, 1(1), 80-85.

Liana, D. (2020). Penerapan Pembelajaran siklus belajar (learning cycle 5e) terhadap hasil belajar ipa siswa kelas VI SDN 007 Kotabaru Kecamatan Keritang. Mitra Pgmi: Jurnal Kependidikan MI, 6(2), 92101.

https://doi.org/10.46963/mpgmi.v6i1.127

Mahmud, N. (2020). Meningkatkan hasil belajar matematika operasioanl perkalian melalui pendekatan matematika realistik pada siswa kelas IV Sekolah Dasar Inpres Sopi Kecamatan Morotai Jaya. Jurnal Mitra Pendidikan, 4(6), 392-403.

Panjaitan, S. (2015). Efektifitas alat peraga model kartu positif dan negatif terahadap 
hasil belajar. Jurnal Pendidikan Matematika Dan Terapan, 1(3), 82-91.

Pitriana, P., Agustina, R. D., Zakwandi, R., Ijharudin, M., \& Kurniawan, D. T. (2018). Fun Science: Roket air sebagai media edu-sains untuk meningkatkan motivasi belajar peserta didik sekolah dasar. Jurnal Inovasi Pendidikan Fisika Dan Riset Ilmiah, 2(1), 1-7. https://doi.org/10.30599/jipfri.v2i1.143

Putri, M. S. (2016). Penggunaan media kartu bilangan positif negatif sebagai upaya meningkatkan prestasi belajar materi penjumlahan dan pengurangan bilangan bulat siswa kelas IV SD Negeri Delegan II Prambanan. Universitas Negeri Yogyakarta.

Rachmawati, T. K., Suhendar, Y., \& Akbar, R. (2018). Penggunaan kartu positif negatif dalam menyelesaikan operasi hitung bilangan bulat. 50-56.

Rahayuningsih, R., Masykuri, M., \& Utami, B. (2012). Penerapan siklus belajar 5e (learning cycle 5e) untuk meningkatkan kualitas proses dan hasil belajar kimia pada materi kelarutan dan hasil kali kelarutan kelas XI IPA SMA Negeri 1 Kartasura Tahun Pelajaran 2011/2012. Jurnal Pendidikan Kimia Universitas Sebelas Maret, 1(1), 127449.

Rahimah, N., \& Asy'ari, A. (2017). Keterampilan dasar geometri siswa kelas $\mathrm{v}$ dalam menyelesaikan soal bangun datar berdasarkan kemampuan matematika di MI Al Istiqomah Banjarmasin. Math Didactic: Jurnal Pendidikan Matematika, 3(1), https://doi.org/10.33654/math.v3i1.55

Sinaga, R. F. (2018). Efektivitas alat peraga model kartu positif dan negatif terhadap prestasi belajar. Jurnal Pendidikan Matematika Dan Terapan, 3(1), 16-25.

Susilawati, Susilawati, \& Sridana, N. (2015). Pengaruh model pembelajaran inkuiri terbimbing terhadap keterampilan proses sains siswa. BIOTA: Jurnal Tadris IPA
Biologi FTIK IAIN Mataram, 8(1), 27-36.

Wahyuni, H. T., Setyosari, P., \& Kuswandi, D. (2016). Implementasi pembelajaran tematik kelas 1 SD. Edcomtech, 1(2), 129136.

Waskitoningtyas, R. S. (2016). Analisis kesulitan belajar matematika siswa kelas $\mathrm{v}$ sekolah dasar kota Balikpapan pada materi satuan waktu tahun ajaran 2015/2016. JIPM (Jurnal Ilmiah Pendidikan Matematika), 5(1), 24. https://doi.org/10.25273/jipm.v5i1.852

Widyastuti, N. S., \& Pujiastuti, P. (2014). Pengaruh pendidikan matematika realistik indonesia (PMRI) terhadap pemahaman konsep dan berpikir logis siswa. Prima Edukasia, 2(2), 183-193. 